\title{
FAKTOR-FAKTOR INTERNAL YANG MEMPENGARUHI PENGHENTIAN PREMATUR ATAS PROSEDUR AUDIT
}

\author{
Jessica Vianto \\ Sugi Suhartono* \\ Program Studi Akuntansi, Institut Bisnis dan Informatika Kwik Kian Gie, \\ Jl. Yos Sudarso Kav. 87, Jakarta 14350
}

\begin{abstract}
This study aims to analyze the internal factors that affect the premature sign-off. These internal factors are the locus of control, self-esteem in relation to ambition, turnover intentions and the auditor's experience of premature sign-off of audit procedure.This research was conducted by distributing questionnaires to 23 Non-Big-Four Public Accountant Firm in Jakarta and getting 108 auditors as respondents. The results of this study indicate that the locus of control has a significant value of 0.000. The significant value of the self-esteem in relation to ambition of0.099. While the significant result of turnover intention is 0.110. And the auditor's experience is 0.001. It was concluded that the proven locus of control had a positive effect on premature sign-off of the audit procedure, while there was insufficient evidence that self-esteem associated with ambition and stopping desire had a positive effect on the premature sign-off of audit procedures. Nor is it sufficient evidence that the auditor's experience negatively affects premature sign-off of audit procedures.
\end{abstract}

Keywords : Premature sign off, Locus of control, Self esteem, Turnover intentions

\begin{abstract}
ABSTRAK
Penelitian ini bertujuan untuk menganalisis faktor-faktor internal yang memengaruhi penghentian prematur atas prosedur audit.Faktor-faktor internal tersebut ialah lokus kendali, harga diri terkait dengan ambisi, keinginan untuk berhenti bekerja dan pengalaman auditor terhadap penghentian prematur atas prosedur audit. Penelitian ini dilakukan dengan cara menyebarkan kuesioner kepada 23 Kantor Akuntan Publik Non Big-Four di Jakarta dan mendapatkan108 auditorsebagai responden. Hasil penelitian ini menunjukkan bahwa lokus kendali memiliki nilai signifikan sebesar 0,000.Nilai signifikan dari variabel harga diri terkait dengan ambisi sebesar 0,099.Sedangkan hasil signifikan keinginan berhenti bekerjasebesar 0,110.Dan pengalaman auditor sebesar 0,001. Disimpulkan bahwa terbukti lokus kendali berpengaruh positif terhadap penghentian prematur atas prosedur audit, sedangkan tidak cukup bukti bahwa harga diri terkait dengan ambisi dan keinginan berhenti bekerja berpengaruh positif terhadap penghentian prematur atas prosedur audit.Dan juga tidak cukup bukti bahwa pengalaman auditor berpengaruh negatif terhadap penghentian prematur atas prosedur audit.
\end{abstract}

Kata kunci : Penghentian prematur, Lokus kendali, Harga diri, Keinginan berhenti

*Alamat kini:Institut Bisnis dan Informatika Kwik Kian Gie,Jl. Yos Sudarso Kav 87,Sunter,Jakarta 14350 Penulis untuk Korespondensi: (021) 65307062 Ext. 708. Email: sugi.suhartono@kwikkiangie.ac.id 


\section{Pendahuluan}

Penghentian prematur adalah pengabaian atau pengurangan prosedur audit yang telah disyaratkan oleh auditor. Prosedur audit merupakan langkah-langkah yang harus dilaksanakan dalam melakukan audit, namun pada prakteknya auditor mengurangi langkahlangkah dalam melakukan audit, seperti pengurangan jumlah sampel, melakukan review dangkal terhadap dokumen klien, dan tidak memperluas pemeriksaan jika terdapat pos yang dipertanyakan (Kumalasari, 2013).

Penghentian prematur ini memengaruhi opini yang dibuat oleh auditor. Sebab semakin banyak prosedur audit yang ditinggalkan maka kemungkinan opini yang buat oleh auditor kurang tepat bahkan memungkinkan terjadi kesalahan pemberian opini. Akibat dari perilaku penghentian prematur adalah tidak validnya informasi yang telah dikumpulkan auditor dan tidak akuratnya laporan keuangan yang telah diaudit. Selain itu, praktek penghentian prematur ini juga dapat penurunan kepercayaan publik atas profesi akuntan atau auditor itu sendiri.

Fenomena perilaku yang dapat mengurangi kualitas audit yang dilakukan oleh auditor pada saat melakukan audit semakin banyak terjadi, dengan kasus baru-baru ini terjadi pada akuntan publik mitra Ernst \& Young (EY) di Indonesia, yakni KAP Purwantono, Suherman, dan Surja pada bulan Februari 2017. Dalam ketergesaan mereka atas untuk mengeluarkan laporan audit untuk kliennya, Ernst \& Young (EY) di Indonesia dan dua mitranya lalai dalam menjalankan tugas dan fungsinya untuk memperoleh bukti audit yang cukup. PT. Indosat tidak memberikan bukti yang memadai mengenai penyewaan 4000 menara selular dan auditor memberikan opini wajar tanpa pengecualian, padahal perhitungan dan pemeriksaan belum selesai.

Penghentian prematur dapat terjadi dikarenakan faktor internal auditor dan eksternal dari auditor tersebut. Faktor internal merupakan karakteristik auditor atau disebut juga dengan perilaku dari auditor itu sendiri, sedangkan faktor eksternal merupakan situasi yang dihadapi oleh auditor dalam melakukan audit. Tindakan tersebut dapat berpengaruh langsung terhadap kualitas laporan audit yang dihasilkan auditor, apabila salah satu langkah dalam prosedur audit dihilangkan, maka kemungkinan auditor membuat judgement yang salah akan semakin tinggi (Qurrahman, Susfayetti, Mirdah, 2012).

Faktor internal yang memengaruhi penghentian premature atas prosedur audit adalah locus of control. Locus of control adalah variabel kepribadian yang didefinisikan sebagai keyakinan individu terhadap mampu tidaknya mengontrol nasib (destiny) sendiri (Robbins, 2006). Rochman, Rita dan Abrar (2016) melakukan penelitian pada KAP di Semarang dan menyatakan bahwa locus of control memiliki hubungan signifikan positif terhadap penghentian prematur atas prosedur audit. Hal ini bertolak belakang dengan hasil dari penelitian Andani dan Mertha (2014) yang melakukan penelitian pada kantor BPK-RI di Bali, yaitu locus of control memiliki pengaruh signifikan negatif terhadap penghentian prematur atas prosedur audit.

Praktek penghentian prosedur audit dapat disebabkan juga oleh karakteristik personal auditor (faktor internal) yaitu self esteem in relation ambition. Menurut Robbins (2006), self esteem merupakan suatu variabel kepribadian yang mengukur derajat suka atau tidak suka seorang individu terhadap dirinya sendiri. Safriliana dan Nancy (2016) melakukan penelitian pada KAP di Jawa Timur menyatakan self esteem in relation to ambition berpengaruh positif signifikan terhadap penghentian prematur atas prosedur audit. Sedangkan menurut Akbari (2015), self esteem in relation to ambition tidak berpengaruh signifikan terhadap penghentian prematur atas prosedur audit.

Turnover intentions (keinginan untuk berhenti), keinginan (kesadaran atau kesengajaan) individu untuk meninggalkan organisasi dan mencari alternatifpekerjaan di tempat lain (Setiawan dan Ghozali, 2006:15). Handayani (2016) melakukan penelitian pada KAP di Pekanbaru, Padang dan Medan menyatakan turnover intention berpengaruh terhadap penghentian prematur atas prosedur audit dengan nilai sig sebesar 0,007. Namun menurut Safriliana dan Nancy (2016), turnover intention tidak berpengaruh terhadap penghentian prematur atas prosedur audit dengan nilai sig sebesar 0,676.

Sedangkan pengalaman kerja dapat memperdalam dan memperluas kemampuan 
kerja. Semakin sering seseorang melakukan pekerjaan yang sama, semakin terampil dan semakin cepat dia menyelesaikan pekerjaan tersebut. Semakin banyak macam pekerjaan yang dilakukan seseorang, pengalaman kerjanya semakin kaya dan luas dan memungkinkan peningkatan kinerja. Menurut Budiman (2013) bahwa pengalaman auditor berpengaruh positif terhadap penghentian prematur atas prosedur audit. Sedangkan hasil penelitian Indarto (2011) menyatakan bahwa pengalaman auditor tidak berpengaruh terhadap penghentian prematur atas prosedur audit. Peneliti merumuskan masalah sebagai berikut : "Apakah locus of control, self esteem in relation to ambition, turnover intention dan pengalaman auditor terhadap penghentian prematur atas prosedur audit?" Tujuan dari penelitian ini adalah 1) Untuk mengetahui pengaruh locus of control terhadap penghentian prematur atas prosedur audit. 2) Untuk mengetahui pengaruh self esteem in relation to ambition terhadap penghentian prematur atas prosegdur audit. 3) Untuk mengetahui pengaruh turnover intention terhadap penghentian prematur atas prosedur audit. 4) Untuk mengetahui pengaruh pengalaman auditor terhadap penghentian prematur atas prosedur audit.

\section{Teori Atribusi}

Teori atribusi merupakan cara untuk menganalisa dan memahami perilaku orang lain dan apa yang dapat disimpulkan dari hal tersebut (Myers, 1996:101). Myers mengembangkan teori atribusi ini dari Fritz Heider yang sebelumnya mengemukakan teori atribusi kausalitas. Fritz Heider menyimpulkan perilaku seseorang ditentukan oleh kombinasi antara kekuatan eksternal (external forces) dan kekuatan internal (internal forces). Kekuatan eksternal (external forces) yaitu faktor-faktor yang berasal dari luar diri orang yang bersangkutan, seperti kesulitan dalam pekerjaan. Sedangkan kekuatan internal (internal forces) yaitu faktor-faktor yang berasal dari dalam diri seseorang, seperti kemampuan dan usaha. Ada tiga faktor yang menjadi dasar pertimbangan dalam menarik kesimpulan apakah suatu perbuatan atau tindakan itu disebabkan oleh faktor di luar diri atau disebabkan oleh sifat dari dalam diri sendiri (Myers, 1996:102), yaitu:

1. Konsensus (consensus) adalah situasi yang membedakan perilaku seseorang dengan perilaku orang lainnya dalam menghadapi situasi yang sama.

2. Konsistensi (consistency) adalah sesuatu yang menunjukkan sejauh mana perilaku seseorang konsisten dari satu situasi ke situasi lain (apakah orang yang bersangkutan cenderung melakukan perilaku yang sama di masa lalu dalam situasi yang sama).

3. Keunikan (distinctiveness) menunjukkan sejauh mana seseorang bereaksi dengan cara yang sama terhadap stimulus atau peristiwa yang berbeda.

4. Perilaku seseorang akan diatribusikan sebagai atribusi eksternal bila perilaku tersebut ditandai dengan konsensus yang tinggi, konsistensi tinggi dan keunikan tinggi, namun akan diatribusikan secara internal bila perilaku tersebut memiliki tingkat konsensus rendah, konsistensi tinggi dan keunikan yang rendah.

\section{Prosedur Audit}

Menurut Agoes (2004:131) prosedur audit (audit procedures) adalah langkahlangkah yang harus dijalankan auditor dalam melaksanakan pemeriksaan dan sangat diperlukan oleh asisten agar tidak melakukan penyimpangan dan dapat bekerja secara efisien dan efektif. Kualitas dari auditor dapat diketahui dari seberapa jauh auditor menjalankan prosedur-prosedur audit yang tercantum dalam program audit.

Prosedur audit yang digunakan oleh penulis adalah prosedur audit yang dilaksanakan pada tahap perencanaan audit dan tahap pekerjaan lapangan yang telah ditetapkan dalam Standar Profesional Akuntan Publik (SPAP), antara lain :

1. Membangun pemahaman bisnis industri klien

Didalam PSA No.05 SA Seksi 310, 2001 menyatakan bahwa auditor harus membangun pemahaman dengan klien tentang jasa yang akan dilaksanakan untuk setiap perikatan. Untuk mengurangi risiko terjadinya salah interpretasi kebutuhan atau 
harapan pihak lain, baik di pihak auditor maupun klien maka perlu dilakukan pemahaman tersebut.

2. Pertimbangan atas pengendalian intern dalam audit laporan keuangan

PSA No.69 SA Seksi 319, 2001 menjelaskan bahwa pengendalian intern adalah suatu proses yang dijalankan oleh dewan komisaris, manajemen, dan personal lain entitas yang didesain untuk memberikan keyakinan memadai tentang pencapaian tiga golongan tujuan. Tiga golongan tujuan tersebut adalah keandalan laporan keuangan, efektifitas dan efisiensi operasi, dan kepatuhan terhadap hukum dan ketentuan yang berlaku.

3. Pertimbangan auditor atas fungsi auditor intern klien

PSA No.33 SA Seksi 322, 2001 menjelaskan bahwa menyediakan jasa analisis dan evaluasi, memberikan keyakinan dan rekomendasi, dan informasi lain kepada manajemen entitas dan dewan komisaris, atau pihak lain yang setara wewenang dan tanggung jawabnya dengan tetap mempertahankan objektivitasnya berkaitan dengan aktivitas yang diaudit merupakan tanggung jawab auditor intern.Tanggung jawab penting fungsi audit intern adalah memantau kinerja pengendalian entitas.

4. Informasi asersi manajemen

PSA No.07 SA Seksi 326, 2001 menjelaskan bahwa asersi adalah pernyataan manajemen yang terkandung di dalam komponen laporan keuangan. Asersi tersebut dapat diklasifikasikan menjadi keberadaan atau keterjadian (existence or occurrence), kelengkapan (completeness), hak dan kewajiban (right and obligation), penilaian(valuation) atau alokasi, serta penyajian dan pengungkapan (presentation and disclosure). Dalam memperoleh bukti audit yang mendukung asersi dalam laporan keuangan, auditor memerlukan informasi asersi manajemen.

5. Prosedur analitik

PSA No.22 SA Seksi 329, 2001 menjelaskan bahwa analitik merupakan bagian penting dalam proses audit dan terdiri dari evaluasi terhadap informasi keuangan. Prosedur analitik membantu auditor dalam merencanakan sifat, saat, dan lingkup prosedur audit lainnya, sebagai pengujian substantif untuk memperoleh bukti tentang asersi tertentu yang berhubungan dengan saldo akun atau jenis transaksi, serta sebagai review menyeluruh informasi keuangan pada tahap review akhir audit merupakan tujuan dilakukannya prosedur analitik.

6. Konfirmasi

PSA No. 07 SA Seksi 330, 2001 menjelaskan konfirmasi adalah proses pemerolehan dan penilaian suatu komunikasi langsung dari pihak ketiga sebagai jawaban atas suatu permintaan informasi tentang unsur tertentu yang berdampak terhadap asersi laporan keuangan. Konfirmasi dilaksanakan untuk memperoleh bukti dari pihak ketiga mngenai asersi laporan keuangan yang dibuat oleh manajemen.

7. Representasi manajemen

PSA No.17 SA Seksi 333, 2001 menjelaskan bahwa representasi manajemen (lisan maupun tertulis) merupakan bagian dari bukti audit yang diperoleh auditor tetapi tidak merupakan pengganti bagi penerapan prosedur audit yang diperlukan untuk memperoleh dasar memadai bagi pendapat auditor atas laporan keuangan. Representasi tertulis bagi manajemen biasanya menegaskan representasi lisan yang disampaikan oleh manajemen kepada auditor, menunjukkan dan mendokumentasikan lebih lanjut ketepatan representasi tersebut, serta mengurangi kemungkinan salah paham mengenai yang direpresentasikan.

8. Pengujian pengendalian Teknik Audit Berbantuan Komputer (TABK)

PSA No.59 SA Seksi 327, 2001 menjelaskan bahwa penggunaan TABK harus dikendalikan oleh auditor untuk memberikan keyakinan memadai bahwa tujuan audit dan spesifikasi rinci TABK telah terpenuhi, serta bahwa TABK tidak dimanipulasi semestinya oleh staf entitas.

9. Sampling audit

PSA No.26 SA Seksi 350, 2001 menjelaskan sampling audit adalah penerapan terhadap prosedur audit terhadap kurang dari seratus persen unsur dalam suatu saldo akun atau kelompok transaksi dengan tujuan untuk menilai beberapa 
karakteristik saldo akun atau kelompok tersebut.

10. Perhitungan fisik

PSA No.7 SA Seksi 331, 2001 menjelaskan perhitungan fisik berkaitan dengan pemeriksaan auditor melalui pengamatan, pengujian, dan permintaan keterangan memadai atas efektifitas metode perhitungan fisik persediaan atau kas dan mengukur keandalan atas kuantitas dan kondisi fisik persediaan atau kas klien.

\section{Penghentian Prematur Atas Prosedur Audit}

Praktik penghentian prematur atas prosedur audit terjadi ketika auditor tidak melaksanakan prosedur audit yang disyaratkan tetapi auditor tetap memberikan opini atas suatu laporan keuangan (Shapeero, et al., 2003). Kemungkinan auditor akan membuat judgment yang salah apabila salah satu langkah dalam prosedur audit dihilangkan. Risiko audit akan meningkat apabila salah satu langkah dalam prosedur audit dihilangkan dan menyebabkan terjadinya tuntutan hukum jika kesalahan material ditemukan oleh pengguna laporan dan mengakibatkan kerugian keuangan (Liantih, 2010).

\section{Locus of Control}

Locus of control merupakan salah satu variabel kepribadian yang didefinisikan sebagai keyakinan individu terhadap mampu tidaknya mengontrol nasib (destiny) sendiri. Individu yang memiliki keyakinan bahwa nasib atau peristiwa-peristiwa dalam kehidupannya berada di bawah kontrol dirinya dikatakan sebagai individu yang memiliki locus of control internal. Sementara itu, individu yang memiliki locus of control eksternal berkeyakinan bahwa lingkunganlah yang mempunyai kontrol terhadap nasib atau peristiwa-peristiwa yang terjadi dalam kehidupannya (Robbins, 2006).

Situasi dimana individu-individu dengan locus of control ekternal merasa tidak mampu dalam mendapatkan dukungan kekuatan yang dibutuhkannya untuk bertahan dalam suatu organisasi, maka mereka akan memiliki potensi untuk mencoba memanipulasi rekan atau objek lainnya sebagai kebutuhan pertahanan mereka. Dalam konteks auditing, manipulasi pada akhirnya akan menimbulkan penyimpangan perilaku dalam audit. Perilaku yang dimaksud salah satunya dapat berbentuk praktik penghentian prematur atas prosedur audit.

$\mathrm{H}_{\mathrm{a} 1}$ : Locus of control eksternal berpengaruh positif terhadap penghentian prematur atas prosedur audit.

\section{Self Esteem in Relation to Ambition}

Menurut Robbins (2006), self esteem merupakan suatu variabel kepribadian yang mengukur derajat suka atau tidak suka seorang individu terhadap dirinya sendiri. Setiap individu memiliki self esteem yang berbedabeda dimana mereka melihat diri mereka sendiri apakah berharga, mampu dan dapat diterima di lingkungan sekitar atau tidak.

Malone dan Robert (1996) mengatakan bahwa individu yang memiliki self esteem tinggi adalah individu yang memiliki komitmen atau prinsip hidup yang lebih baik dalam melakukan segala hal untuk mencapai tujuannya. Individu tersebut dapat mengatasi kegagalan dengan lebih baik karena mereka mempunyai sifat optimis dan tingkat kecemasan yang rendah daripada individu yang memiliki self esteem rendah. Individu yang memiliki harga diri tinggi cenderung memiliki percaya diri berlebihan (overconfidence) dalam bekerja akan merasa mampu melakukan analisis dan memiliki pengetahuan yang pada kenyataannya tidaklah demikian, sehingga mereka tidak akan mengikuti prosedur audit yang sudah disyaratkan.

$\mathrm{H}_{\mathrm{a} 2}$ : Self esteem in relation to ambition berpengaruh positif terhadap penghentian prematur atas prosedur audit

\section{Turnover Intentions}

Keinginan berhenti dari organisasi (turnover intentions) mencerminkan keinginan (kesadaran atau kesengajaan) individu untuk meninggalkan organisasi dan mencari alternatif pekerjaan di tempat lain (Setiawan dan Ghozali, 2006:15). Seorang karyawan akan menunjukkan sikap yang baik secara keseluruhan di tempat kerja apabila ia merasa puas dalam pekerjaannya dan hal tersebut menyebabkan meningkatnya komitmen 
seorang karyawan terhadap organisasi yang akhirnya akan menyebabkan rendahnya niat untuk keluar dari perusahaan (intention to quit).

Auditor dengan keinginan untuk meninggalkan perusahaan lebih mungkin terlibat dalam penghentian prematur atas prosedur audit karena auditor yang sudah memiliki keinginan untuk berhenti akan cenderung mengabaikan tugas dan tanggung jawabnya dikarenakan auditor merasa bahwa mereka tidak akan mendapatkan sanksi.

$\mathrm{H}_{\mathrm{a} 3}$ : Turnover intention berpengaruh positif terhadap penghentian prematur atas prosedur audit

\section{Pengalaman Auditor}

Pengalaman audit adalah keterlatihan dan lama waktu bekerja auditor dalam melaksanakan audit. Menurut Simanjuntak (2005) pengalaman dapat memperdalam dan memperluas kemampuan kerja. Secara psikis, pengalaman akan membentuk pribadi seseorang, yaitu akan membuat seseorang lebih bijaksana baik dalam berpikir maupun bertindak, karena pengalaman seseorang akan merasakan posisinya saat dia dalam keadaan baik dan saat dia dalam keadaan buruk. Secara teknis, semakin banyak tugas yang dikerjakan, akan semakin mengasah keahliannya dalam medeteksi suatu hal yang memerlukan treatment atau perlakuan khusus yang banyak dijumpai dalam pekerjaan dan sangat bervariasi karakteristiknya (Bawono dan Singgih, 2010). Maka dari itu, auditor yang telah berpengalaman memungkinkan dapat mengontrol kemungkinan terjadinya penghentian prematur atas prosedur audit.

$\mathrm{H}_{\mathrm{a} 4}$ : Pengalaman auditor berpengaruh negatif terhadap penghentian prematur atas prosedur audit

\section{Faktor-faktor yang memengaruhi penghentian prematur atas prosedur audit}

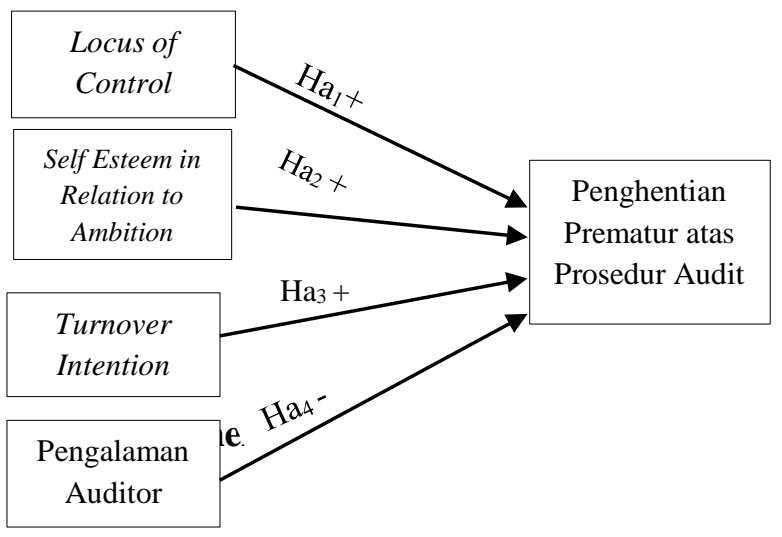

Metode penelitian yang digunakan dalam peelitian ini adalah analisis deskriptif dengan pendekatan survey, karena dalam penelitian ini bersifat menerapkan, mendeskripsikan, atau menjelaskan bagaimana proses pengaruh faktor-faktor yang memengaruhi penghentian prematur atas prosedur audit. Survey dilakukan dengan menyebar kuesioner ke 23 Kantor Akuntan Publik Non Big Four di Jakarta yang terdaftar di Institut Akuntan Publik Indonesia (IAPI). Peneliti menyebarkan 127 kuesioner dan yang kembali hanya 108 kuesioner.

\section{Teknik Pengambilan Sampel}

Teknik pengambilan sampel yang digunakan adalah dengan non probability sampling, yaitu teknik pengambilan sampel yang setiap anggota populasi tidak mempunyai kesempatan untuk dimasukan sebagai sampel (Cooper dan Schindler, 2006:118). Teknik yang diambil adalah judgement sampling yang merupakan teknik pengambilan sampel berdasarkan pertimbangan peneliti, yaitu peneliti memilih KAP Non Big Four sebagai sampel (Cooper dan Schindler, 2006:139).

\section{Teknik Analisis Data}

\section{Statistik Deskriptif}

Pengukuran yang digunakan dalam penelitian ini merupakan pengukuran yang menggambarkan atau mendeskripsikan ikhtisar dari data yang diolah mengenai penghentian prematur atas prosedur audit.

\section{Uji Kualitas Data}

a. Uji Validitas

Pengujian validitas ini menggunakan Pearson Correlation yaitu dengan cara menghitung korelasi antara nilai yang diperoleh dari pertanyaan-pertanyaan. Apabila Pearson Correlation yang didapat memiliki nilai di bawah 0,05 berarti data yang diperoleh adalah valid (Ghozali, 2016:52).

b. Uji Reliabilitas

Kriteria pengujian dilakukan dengan menggunakan pengujian Cronbach Alpha $(\alpha)$. Suatu variabel dikatakan reliable jika memberikan 
nilai Cronbach Alpha > 0,60 (Ghozali, 2016:47).

\section{Uji Asumsi Klasik}

Uji multikolonieritas dilihat dari nilai tolerance dan Variance Inflantion Factor (VIF) (Ghozali, 2016:103). Model regresi yang baik seharusnya tidak terjadi korelasi di antara variabel independen. Suatu model regresi dapat dikatakan bebas multiko jika mempunyai nilai VIF lebih kecil dari 10 dan mempunyai angka tolerance lebih besar dari 0,10 .

\section{a. Uji Normalitas}

Dalam penelitian ini, ujinormalitas menggunakan uji statistik One Sample Kolmogorov-Smirnov Test. Suatu data dikatakan berdistribusi secara normal jika memiliki tingkat signifikan $>0,05$ dan suatu data dikatakan tidak berdistribusi secara normal jika memiliki tingkat signifikan $<0,05$ (Ghazali, 2016:154).

\section{b. Uji Heteroskedastisitas}

Pengujian dilakukan dengan menggunakan grafik Scatterplot, yaitu dengan melihat pola-pola tertentu pada grafik (Ghozali, 2016:134). Salah satu cara untuk mendeteksi ada atau tidaknya heterokedastitas adalah dengan menggunakan grafik Scatterplot antara 50 nilai prediksi variabel terikat (dependen) yaitu ZPRED dengan residualnya SRESID. Apabila nilai probabilitas signifikansinya di atas tingkat kepercayaan lima persen dan grafik Scatterplot, titik-titik menyebar di atas maupun dibawah angka nol pada sumbu Y, maka dapat disimpulkan model regresi tidak mengandung adanya heterokedastisitas. Jika terdapat pola tertentu yang teratur, seperti bergelombang, melebar kemudian menyempit maka menunjukkan telah terjadi heteroskedastisitas.

\section{Regresi Linier Berganda}

Metode analisis data yang dipakai adalah model statistik regresi linier berganda. Data yang didapat dari penelitian ini akan dianalisis dengan menggunakan regression analysis dengan bantuan SPSS, dimana dalam persamaan regresinya adalah:

$$
\begin{aligned}
& \mathrm{Y}=\mathrm{b}_{0}+\mathrm{b}_{1} \mathrm{X}_{1}+\mathrm{b}_{2} \mathrm{X}_{2}+\mathrm{b}_{3} \mathrm{X}_{3}+\mathrm{b}_{4} \mathrm{X}_{4}+\varepsilon \\
& \text { Keterangan : } \\
& \mathrm{Y}=\text { Penghentian prematur atas prosedur } \\
& \text { audit } \\
& \mathrm{a}=\text { konstanta } \\
& \mathrm{b}=\text { koefisien regresi } \\
& \mathrm{X}_{1}=\text { Locus of Control } \\
& \mathrm{X}_{2}=\text { Self Esteem in Relation to Ambition } \\
& \mathrm{X}_{3}=\text { Turnover Intentions } \\
& \mathrm{X}_{4}=\text { Pengalaman Auditor } \\
& \varepsilon \quad=\text { Error }
\end{aligned}
$$

\section{Uji Hipotesis}

\section{a. Uji Statistik F}

Uji statistik $F$ digunakan untuk mengetahui pengaruh semua variabel independen yang dimasukkan dalam model regresi secara bersama-sama terhadap variabel dependen yang diuji pada tingkat signifikan 0,05 (Ghozali, 2016:96). Jika nilai probabilitas lebih besar dari 0,05, dapat dikatakan bahwa semua variabel independen atau bebas tidak mempunyai pengaruh secara bersama-sama terhadap variabel dependen atau terikat. Dan apabila nilai probabilitas lebih kecil dari 0,05, maka dapat dikatakann bahwa semua variabel independen atau bebas mempunyai pengaruh secara bersama sama terhadap variabel dependen atau terikat.

\section{b. Uji Statistik t}

Uji statistik $t$ menunjukkan seberapa jauh pengaruh satu variabel penjelas atau independen secara individual dalam menerangkan variasi variabel dependen dan digunakan untuk mengetahui ada atau tidaknya pengaruh masing-masing variabel independen secara individual terhadap variabel dependen yang diuji pada tingkat signifikansi 0,05 (Ghozali, 2016:97). Jika nilai probabilitas signifikansi t lebih kecil dari 0,05 maka dapat dikatakan bahwa ada pengaruh yang kuat antara variabel independen dengan variabel dependen. Dan jika nilai probabilitas signifikansi t lebih besar dari 0,05 maka dapat dikatakan 
bahwa ada tidak pengaruh yang kuat antara variabel independen dengan variabel dependen.

c. Uji Koefisien Determinasi

Koefisien Determinasi $\left(\mathrm{R}^{2}\right)$ pada intinya mengukur seberapa jauh kemampuan model dalam menerangkan variasi variabel dependen. Nilai koefisien determinasi adalah antara 0 (nol) dan 1 (satu). Nilai $\mathrm{R}^{2}$ yang kecil berarti kemampuan variabel-variabel independen dalam menjelaskan variasi variabel dependen amat terbatas. Nilai yang mendekati satu berarti variabel-variabel independen memberikan hampir semua informasi yang dibutuhkan untuk memprediksi variasi variabel dependen (Ghozali, 2016:95).

\section{Hasil Dan Pembahasan}

\section{Hasil Uji Statistik Deskriptif}

\begin{tabular}{crrcc}
\hline Variabel & Min. & Maks. & Mean & $\begin{array}{c}\text { Std. } \\
\text { Deviasi }\end{array}$ \\
\hline ZLC & 6 & 30 & 16,42 & 5,82 \\
ZSERA & 500 & 20 & 14,99 & 2,89 \\
ZTI & 9 & 20 & 13,44 & 2,54 \\
ZPA & 6 & 25 & 17,20 & 3,59 \\
ZPSO & 10 & 49 & 21,50 & 9,59 \\
\hline
\end{tabular}

Variabel locus of control jawaban minimum responden sebesar 6 dan maksimum sebesar 30, dengan rata-rata total jawaban 16,42 dan standar deviasi 5,82. Variabel self esteem in realtion to ambition jawaban minimum responden sebesar 5 dan maksimum sebesar 20, dengan rata-rata total jawaban 14,99 dan standar deviasi 2,89. Variabel turnover intentions jawaban minimum responden sebesar 9 dan maksimum sebesar 20, dengan rata-rata total jawaban 13,44 dan standar deviasi 2,54 Variabel pengalaman auditor jawaban minimum responden sebesar 6 dan maksimum sebesar 25, dengan rata-rata total jawaban 17,2 dan standar deviasi 3,59 Variabel penghentian prematur atas prosedur audt jawaban minimum responden sebesar 10 dan maksimum sebesar 49 , dengan rata-rata total jawaban 21,5 dan standar deviasi 9,59.

\section{Hasil Uji Validitas}

\begin{tabular}{cccc}
\hline $\begin{array}{c}\text { Butir } \\
\text { Pertanyaan }\end{array}$ & $\begin{array}{c}\text { Pearson } \\
\text { Correlation }\end{array}$ & $\begin{array}{c}\text { Sig }(1- \\
\text { tailed })\end{array}$ & Ket. \\
\hline LC1 & 0.770 & 0.000 & Valid \\
LC2 & 0.819 & 0.000 & Valid \\
LC3 & 0.784 & 0.000 & Valid \\
LC4 & 0.869 & 0.000 & Valid \\
LC5 & 0.910 & 0.000 & Valid \\
LC6 & 0.839 & 0.000 & Valid \\
SERA1 & 0.717 & 0.000 & Valid \\
SERA2 & 0.837 & 0.000 & Valid \\
SERA3 & 0.813 & 0.000 & Valid \\
SERA4 & 0.798 & 0.000 & Valid \\
TI1 & 0.698 & 0.000 & Valid \\
TI2 & 0.792 & 0.000 & Valid \\
TI3 & 0.766 & 0.000 & Valid \\
TI4 & 0.455 & 0.000 & Valid \\
\hline PA1 & 0.781 & 0.000 & Valid \\
PA2 & 0.701 & 0.000 & Valid \\
PA3 & 0.629 & 0.000 & Valid \\
PA4 & 0.726 & 0.000 & Valid \\
PA5 & 0.700 & 0.000 & Valid \\
PSO1 & 0.845 & 0.000 & Valid \\
PSO2 & 0.798 & 0.000 & Valid \\
PSO3 & 0.865 & 0.000 & Valid \\
PSO4 & 0.793 & 0.000 & Valid \\
PSO5 & 0.914 & 0.000 & Valid \\
PSO6 & 0.842 & 0.000 & Valid \\
PSO7 & 0.852 & 0.000 & Valid \\
PSO8 & 0.810 & 0.000 & Valid \\
PSO9 & 0.682 & 0.000 & Valid \\
PSO10 & 0.835 & 0.000 & Valid \\
\hline & & &
\end{tabular}

Variabel locus of control, self esteem in relation to ambition, turnover intentions, pengalaman auditor dan penghentian prematur atas prosedur audit memiliki kriteria valid untuk setiap butir pertanyaan dengan nilai signifikansi lebih kecil dari 0,05. Oleh karena itu, maka dapat dilakukan uji lebih lanjut, yaitu uji reliabilitas, uji asumsi klasik dan uji hipotesis.

\section{Hasil Uji Reliabilitas}

\begin{tabular}{ccc}
\hline Variabel & $\begin{array}{c}\text { Cronbach's } \\
\text { Alpha }\end{array}$ & Ket. \\
\hline $\begin{array}{c}\text { Locus of Control } \\
\text { Self Esteem in }\end{array}$ & 0.910 & $\begin{array}{c}\text { Reliable } \\
\text { Realtion to } \\
\text { Ambition }\end{array}$ \\
$\begin{array}{c}\text { Turnover } \\
\text { Intentions }\end{array}$ & 0.797 & \\
Pengalaman \\
Auditor
\end{tabular}




\begin{tabular}{ccc}
\hline Penghentian & 0.948 & Reliable \\
Prematus atas & & \\
Prosedur Audit & & \\
\hline
\end{tabular}

Berdasarkan hasil pengujian reliabilitas yang telah dilakukan yang tertuang pada tabel di atas, terlihat dari keseluruhan item pernyataan pada setiap variabel memiliki nilai koefisien Cronbach's Alpha di atas 0,60 maka dapat disimpulkan bahwa seluruh butir pernyataan dalam kuesioner untuk setiap variabel dalam penelitian ini dinyatakan handal (reliabel).

\section{Hasil Uji Multikolinieritas}

\begin{tabular}{ccc}
\hline Variabel & \multicolumn{2}{c}{ Uji Multikolinieritas } \\
& VIF & Tolerance \\
\hline LC & 1,512 & 0,661 \\
SERA & 1,683 & 0,594 \\
TI & 1,405 & 0,712 \\
PA & 1,943 & 0,515 \\
\hline
\end{tabular}

Berdasarkan perhitungan SPSS 20, dapat dilihat pada tabel diatas bahwa nilai Tolerance pada variabel independen $>0,1$ dan semua nilai VIF < 10, sehingga dapat diartikan bahwa tidak terdapat korelasi antar variabel independen.

\section{Hasil Uji Normalitas}

\begin{tabular}{l}
$\begin{array}{l}\text { Uji Normalitas } \\
\text { (Sig 1-tailed) }\end{array}$ \\
\hline 0,1015 \\
\hline
\end{tabular}

Pengujian normalitas menggunakan One-Sample Kolmogorov Smirnov Test, diperoleh nilai sig adalah $0,1015>$ nilai $\alpha(0,05)$ yang berarti data berdistribusi normal.

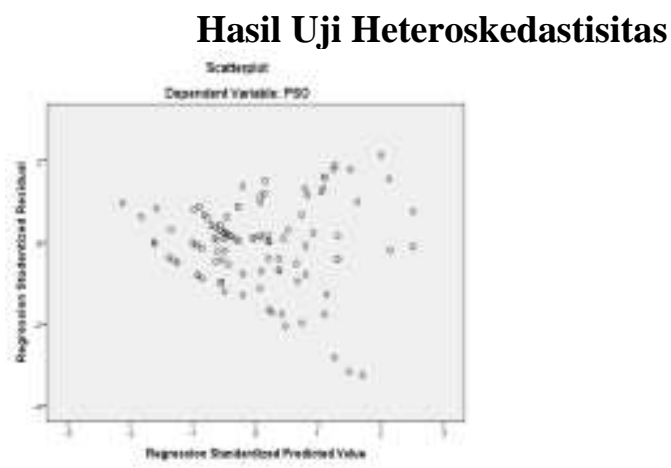

Grafik Scatterplot menunjukkan bahwa data tersebar di atas dan di bawah angka 0 (nol) pada sumbu $\mathrm{Y}$ dan tidak terdapat suatu pola yang jelas pada penyebaran data tersebut. Hal ini berarti tidak terjadi heteroskedastisitas pada model persamaan regresi, sehingga model regresi layak digunakan untuk memprediksi penghentian prematur atas prosedur audit berdasarkan variabel yang memengaruhinya, yaitu locus of control, self esteem in relation to ambition, turnover intentions serta pengalaman auditor.

Tabel Hasil Uji Regresi

\begin{tabular}{|c|c|c|}
\hline Model & $\mathrm{B}$ & Sig \\
\hline Konstan & 0,275 & 0,2945 \\
\hline Locus of Control & 0,552 & 0,000 \\
\hline Self Esteemn in & $-0,163$ & 0,099 \\
\hline Relation & & \\
\hline Ambition & & \\
\hline $\begin{array}{l}\text { Turnover } \\
\text { Intentions }\end{array}$ & $-0,162$ & 0,110 \\
\hline $\begin{array}{l}\text { Pengalaman } \\
\text { Auditor }\end{array}$ & 0,442 & 0,001 \\
\hline
\end{tabular}

\section{Hasil Uji Regresi Berganda}

Metode analisis data yang dipakai adalah model statistik regresi linier berganda. Data yang didapat dari penelitian ini akan dianalisis dengan menggunakan regression analysis dengan bantuan SPSS, dimana dalam persamaan regresinya adalah$$
\mathrm{Y}=0.275+0.552 \mathrm{X}_{1}-0.163 \mathrm{X}_{2}-0.162 \mathrm{X}_{3}
$$
$+0.442 X_{4}$

Keterangan :

$\mathrm{Y}=$ Penghentian prematur atas prosedur audit

$\mathrm{X}_{1} \quad=$ Locus of Control

$\mathrm{X}_{2}=$ Self Esteem in Relation to Ambition

$\mathrm{X}_{3} \quad=$ Turnover Intentions

$\mathrm{X}_{4} \quad=$ Pengalaman Auditor

\section{Hasil Uji Statistik F}

\begin{tabular}{cc}
\hline Model & Sig \\
\hline Regression & 0,000 \\
\hline
\end{tabular}

Berdasarkan uji F yang telah dilakukan, diperoleh bahwa hasil sig. $\mathrm{F}$ adalah $0.000<$ 
0,05. Ini berarti bahwa locus of control, self esteem in relation to ambition, turnover intentions serta pengalaman auditor secara bersama-sama berpengaruh terhadap penghentian prematur atas prosedur audit.

\section{Hasil Uji Statistik t}

Dapat dilihat pada tabel hasil uji regresi, variabel locus of control menunjukkan tingkat signifikan sebesar $0,000<0,05$ dan nilai $\mathrm{B}$ sebesar 0,552 maka dalam pengujian ini tolak $\mathrm{H}_{\mathrm{o} 1}$ dan terima $\mathbf{H}_{\mathbf{a} 1}$ yang berarti bahwa locus of control berpengaruh positif terhadap penghentian prematur atas prosedur audit. Hal ini membuktikan bahwa semakin tinggi locus of control maka semakin tinggi penghentian prematur atas prosedur audit. Individu yang memiliki locus of controlekternal akan merasa tidak mampu dan kurang usahanya dalam menghadapi masalah dan kegagalan saat bekerja sehingga mereka akan melakukan tindakan manipulasi atau penipuan dalam pekerjaan auditnya. Hasil ini sejalan dengan hasil penelitian Budiman (2013) yang menyatakan bahwa auditor yang memiliki locus of control berhubungan positif dengan penghentian prematur atas prosedur audit.

Variabel self esteem in relation to ambition menunjukkan tingkat signifikan sebesar 0,099>0,05 dan nilai B sebesar -0,163 maka dalam pengujian ini tolak $\mathrm{H}_{\mathrm{a} 2}$ dan terima $\mathbf{H}_{\mathbf{0} 2}$ yang berarti bahwa self esteem in relation to ambition tidak berpengaruh terhadap penghentian prematur atas prosedur audit. Auditor dengan self esteem yang tinggi tidak meremehkan prosedur audit yang berlaku. Auditor akan tetap memperhatikan kinerja mereka dalam bekerja sehingga ambisi mereka untuk mencapai suatu tujuan dapat tercapai. Hasil penelitian ini sejalan dengan hasil penelitian Akbari (2015) yang menyatakan bahwa self esteem in relation to ambition tidak berhubungan dengan penghentian prematur atas prosedur audit.

Hasil uji statistik $t$ variabel turnover intentions menunjukkan tingkat signifikan sebesar 0,110>0,05 dan nilai B sebesar 0,162 maka dalam pengujian ini tolak $\mathrm{H}_{\mathrm{a} 3}$ dan terima $\mathbf{H}_{\mathbf{0}}$ yang berarti bahwa turnover intentions tidak berpengaruh terhadap penghentian prematur atas prosedur audit. Rata-rata responden dari penelitian ini merupakan junior auditor yang belum lama bekerja di KAP sehingga belum ada rencana untuk berhenti bekerja dan auditor akan tetap bertanggung jawab terhadap tugasnya dengan sebaik mungkin serta mengerjakan tugas sesuai prosedur. Auditor yang memiliki keinginan untuk berhenti bekerja juga masih memiliki rasa takut akan kemungkinan diberi sanksi apabila tindakan penghentian prematur atas prosedur audit terdeteksi. Hasil ini sejalan dengan hasil penelitian Safriliana dan Nancy (2016) bahwa turnover intention tidak berpengaruh terhadap penghentian prematur atas prosedur audit.

Hasil uji statistik t variabel pengalaman audit menunjukkan tingkat signifikan sebesar $0,001<0,05$ dan nilai $B$ sebesar 0,442 maka dalam pengujian ini terima $\mathrm{H}_{04}$ dan tolak $\mathbf{H}_{\mathbf{a} 4}$ yang berarti bahwa pengalaman audit berpengaruh positif terhadap penghentian prematur atas prosedur audit. Dengan pengalaman yang banyak, auditor cenderung segan mengikuti prosedur audit dikarenakan sudah merasa berpengalaman sehingga hanya menggunakan kemampuan pribadi yang menurut auditor sudah benar.Dengan hanya menggunakan kemampuan pribadi, maka akan cenderung melakukan penghentian prematur atas prosedur audit karena cara mengaudit hanya menurut pandangan pribadi audior. Hal ini membuktikan bahwa semakin tinggi pengalaman audit maka semakin tinggi penghentian prematur atas prosedur audit. Hasil ini sejalan dengan hasil penelitian Budiman (2013) yang menyatakan bahwa pengalaman auditberpengaruh positif terhadap penghentian prematur atas prosedur audit.

\section{Hasil Uji Koefisien Determinasi}

$\frac{. \text { Adjusted R square }}{0,450}$

Berdasarkan hasil uji koefisien determinan yang dapat dilihat pada tabel 4.14, diperoleh nilai $\mathrm{R}^{2}$ sebesar 0,429 atau sebesar $42,9 \%$. Hal ini berarti bahwa variabel penghentian prematur atas prosedur audit dapat dijelaskan sebesar 42,9\% oleh variabel locus of control, 
self esteem in relation to ambition, turnover intentions dan pengalaman auditor. Sedangkan sisanya sebesar 0,571 atau $57,1 \%$ dijelaskan oleh faktor-faktor lain yang tidak disertakan dalam model penelitian ini.

\section{Kesimpulan Dan Saran}

Berdasarkan pembahasan sebelumnya, peneliti dapat menyimpulkan bahwa terbukti bahwa locus of control berpengaruh positif terhadap penghentian prematur atas prosedur audit. Namun tidak cukup bukti bahwa self esteem in relation to ambition, turnover intentions berpengaruh positif terhadap penghentian prematur atas prosedur audit. Begitu juga bahwa pengalaman audit berpengaruh negatif terhadap penghentian prematur atas prosedur audit.

Penelitian ini memiliki keterbatasan yang perlu diperbaiki di penelitian-penelitian selanjutnya. Keterbatasan itu berupa dalam penelitian ini, responden yang menjadi objek penelitian hanyalah auditor yang berasal dari KAP non-big four. Oleh karena itu, penelitian selanjutnya sebaiknya juga menyertakan auditor yang berasal dari KAP big four sebagai objek penelitian agar penelitian lebih luas dan akan terlihat perbedaan penghentian prematur atas prosedur audit dari dua kelompok KAP yang berbeda. Hasil jawab kuesioner dari auditor pada satu KAP sama semua. Maka dari itu lebih baik penelitian selanjutnya dapat menggunakan metode wawancara langsung kepada responden agar mendapat jawaban yang berbeda-beda dari masing-masing individu. Terdapatnya kendala saat mengambil kembali kuesioner karena orang yang bertanggung jawab saat menerima berkas kuesioner susah dicari saat waktu pengambilan. Lebih baik untuk meminta nomor pribadi dari orang tersebut.

\section{Daftar Pustaka}

Agoes, Sukrisno. 2004. Auditing (Pemeriksaan Akuntansi) oleh Kantor Akuntan Publik. Edisi Ketiga. Jakarta : Fakultas Ekonomi Universitas Indonesia.
Akbari, Akhirumi Zakiah. 2015. "Pengaruh Faktor Situasional dan Faktor Karakteristik Personal Auditor Terhadap Premature Sign Off (Studi Empiris Pada Kantor Akuntan Publik Pekanbaru, Padang dan Palembang)", Jurnal FEKON Vol. 2 No. 1.

Andani, Ni Made Surya dan I Made Mertha. 2014. "Pengaruh Time Pressure, Audit Risk, Proffesional Commitment dan Locus of Control Pada Penghentian Prematur Prosedur Audit". E-Jurnal Akuntansi Universitas Udayana $6.2 \mathrm{hlm}$. 185-196

Bawono, I. R., \& Singgih, E. M. 2010.“Faktorfaktor dalam Diri Auditor dan Kualitas Audit (Studi pada KAP Big Four di Indonesia)".Jurnal Akuntansi Universitas Jenderal Soedirman Purwokerto.

Budiman. 2013. "Pengaruh Faktor Internal dan Eksternal Auditor Terhadap Penghentian Prematur Atas Prosedur Audit (Studi Empiris Pada Kantor Akuntan Publik di Jawa Tengah dan Daerah Istimewa Yogyakarta)", Jurnal Dinamika Ekonomi \& Bisnis, Vol. 10, No. 2.

Cooper, Donald R., Pamela S.Schindler (2006), Metode Riset Bisnis, Edisi 9, New York: McGraw-Hill Irwin

Coram, Paul et al. 2004. The Moral Intensity of Reduced Audit Quality Acts.Working paper, The University of Melbourne.

Ghozali, Imam. 2016. Aplikasi Analisis Multivariate dengan Program SPSS. Cetakan IV. Badan Penerbit Universitas Diponegoro. Semarang.

Handayani, Vina. 2016. "Pengaruh Time Pressure, Risiko Audit, Turnover Intention, Prosedur Review dan Kontrol Kualitas Terhadap Penghentian Prematur Atas Prosedur Audit (Studi Empiris Pada Auditor Kantor Akuntan Publiik di Pekanbaru, Padang, dan Medan)", Jurnal FEKON Vol. 3 No. 1. 
Haryanto, S.M. 2015. "Faktor Eksternal dan Internal Yang Memengaruhi Auditor Dalam Penghentian Prematur Atas Prosedur Audit'.Skripsi. Universitas Hasanuddin.

Kumalasari, Handayani, Wibisono. 2013. "Pengaruh Penghentian Prematur Atas Prosedur Audit Pada Auditor Di KAP Surabaya", Jurnal Riset Manajemen dan Akuntansi, Vol. 1, No. 1.

Liantih, Rahmah. 2010. "Analisis FaktorFaktor yang Mempengaruhi Penghentian Prematur Atas Prosedur Audit". Skripsi.UIN Syarif Hidayatullah.

Malone, Charles F dan Robin W. Roberts. 1996. Factors Associated with the Incidence of Reduced Audit Quality Behaviors. Auditing: A Journal of Practice and Theory.

Myers, David G. (2014), Social Psychology, Edisi 11, New York: McGraw-Hill.

Qurrahman, Susfayetti, Mirdah. (2012). "Pengaruh Time Pressure, Risiko Audit, Materialitas,Prosedur Review dan Kontrol Kualitas, Locus of Control serta Komitmen Profesional Terhadap Penghentian Prematur Prosedur Audit (Studi Empiris pada KAP di Palembang)", Jurnal Binar Akuntansi, Vol. 1, No. 1.

Premature Sign-Off in Public Accounting. Management Auditing Journal, 478-489.

Simanjuntak, Payaman J. (2005),Manajemen dan Evaluasi Kinerja. Jakarta: Lembaga Penerbit Fakultas Ekonomi UI.
Indarto, Stefani Lily. 2011. "Analisis FaktorFaktor yang Mempengaruhi Penghentian Prematur atas Prosedur Audit". Dinamika Sosial Ekonomi Vol. 7 No. 2.

Rochman, Mochamad Nur, Rita Andini, Abrar Oemar. (2016). "Pengaruh Time Pressure, Resiko Audit, Materialitas, Prosedur Review dan Kontrol Kualitas, Locus of Control Serta Komitmen Profesional Terhadap Penghentian Prematur Atas Prosedur Audit", Journal Of Accounting, Vol. 2, No. 2.

Robbins, Stephen P. 2006. "Perilaku Organisasi”.'Edisi Kesepuluh. Jakarta : PT. Indeks Kelompok Gramedia.

Safriliana, Retna dan Nancy Indah Susanti Boreel. 2016. "Analisis Faktor-Faktor Yang Mempengaruhi Penghentian Prematur Atas ProsedurAudit (Studi Empiris Auditor KAP di Jawa Timur)". Jurnal Akuntansi Aktual, Vol. 3, Nomor 3, Januari 2016, hlm. 226-235

Setiawan, Ivan Aries dan Imam Ghozali. 2006. "Akuntansi Keperilakuan: Konsep dan Kajian Empiris Perilaku Akuntansi". Badan Penerbit Universitas Diponegoro, Semarang.

Shapeero, Mike, Hian Chye Koh dan Larry N. Killough. (2003). Underreporting and

Weningtyas, Suryanita, Doddy Setiawan dan Hanung Triatmoko. 2006. "Penghentian Prematur atas Prosedur Audit". Simposium Nasional Akuntansi 9 Padang. 


\section{KUESIONER PENELITIAN \\ FAKTOR-FAKTOR YANG MEMENGARUHI AUDITOR DALAM PENGHENTIAN PREMATUR ATAS PROSEDUR AUDIT}

Isilah dengan singkat dan jelas berdasarkan diri Bapak/Ibu dengan memberi tanda $(\sqrt{ })$ pada jawaban yang telah disediakan.

Tanggal Pengisian :

Nama KAP :

- Jenis Kelamin Anda :

$\square$ Pria

$\square$ Wanita

- Pendidikan Anda :

$\square$ D3

$\square \mathrm{S} 1$

$\square \mathrm{S} 2$

$\square \mathrm{S} 3$

- Posisi Anda saat ini adalah :

$\square$ Junior Auditor

$\square$ Senior Auditor

$\square$ Supervisor

$\square$ Manager

$\square$ Partner

- Berapa lama Anda bekerja sebagai auditor?

$\square<1$ tahun

$\square$ 1-3 tahun

$\square>3$ tahun 


\section{Locus of Control}

Petunjuk : Berilah tanda $(\sqrt{ })$ pada pertanyaan dibawah ini sesuai dengan penilaian anda, dimana :

$1=$ Sangat Tidak Setuju $($ STS $) 3=\operatorname{Netral}(\mathbf{N})$

5 = Sangat Setuju (SS)

2 = Tidak Setuju (TS)

4 = Setuju $(S)$

\begin{tabular}{|c|c|c|c|c|c|c|}
\hline No & Pernyataan & STS & TS & $\mathbf{N}$ & $\mathbf{S}$ & SS \\
\hline 1. & $\begin{array}{l}\text { Pada umumnya untuk mendapatkan pekerjaan yang } \\
\text { anda inginkan tergantung nasib. }\end{array}$ & & & & & \\
\hline 2. & $\begin{array}{l}\text { Untuk memperoleh pekerjaan yang benar-benar } \\
\text { baik, anda membutuhkan koneksi dengan orang } \\
\text { yang mempunyai kedudukan tinggi. }\end{array}$ & & & & & \\
\hline 3. & $\begin{array}{l}\text { Untuk mendapatkan pekerjaan yang cocok, koneksi } \\
\text { yang anda miliki lebih penting dari pada } \\
\text { kemampuan yang anda punyai. }\end{array}$ & & & & & \\
\hline 4. & $\begin{array}{l}\text { Kenaikan jabatan (promosi) lebih merupakan } \\
\text { masalah nasib baik seseorang. }\end{array}$ & & & & & \\
\hline 5. & $\begin{array}{l}\text { Besar kecilnya penghasilan seseorang tergantung } \\
\text { pada nasib baik. }\end{array}$ & & & & & \\
\hline 6. & $\begin{array}{l}\text { Perbedaan utama antara orang-orang yang } \\
\text { mendapatkan penghasilan yang banyak dan orang } \\
\text { yang mendapatkan penghasilan yang sedikit adalah } \\
\text { keberuntungan. }\end{array}$ & & & & & \\
\hline
\end{tabular}

\section{Self Esteem in Relation to Ambition}

Petunjuk : Berilah tanda $(\sqrt{ })$ pada pertanyaan dibawah ini sesuai dengan penilaian anda, dimana :

$1=$ Sangat Tidak Setuju $($ STS $) 3=$ Netral $(N) \quad 5=$ Sangat Setuju $($ SS $)$

$2=$ Tidak Setuju (TS) $\quad 4=$ Setuju $($ S)

\begin{tabular}{|c|l|c|c|c|c|c|}
\hline No & \multicolumn{1}{|c|}{ Pernyataan } & STS & TS & N & S & SS \\
\hline 1. & $\begin{array}{l}\text { Anda cenderung membina hubungan yang baik } \\
\text { dengan rekan kerja. }\end{array}$ & & & & & \\
\hline 2. & Menurut anda aktualisasi diri harus dicapai. & & & & & \\
\hline 3. & $\begin{array}{l}\text { Anda merasa organisasi ini dan rekan-rekan kerja } \\
\text { anda membutuhkan anda. }\end{array}$ & & & & & \\
\hline 4. & $\begin{array}{l}\text { Anda ingin disukai dan dihormati teman-teman } \\
\text { sekerja anda. }\end{array}$ & & & & \\
\hline
\end{tabular}




\section{Turnover Intention}

Petunjuk : Berilah tanda $(\sqrt{ })$ pada pertanyaan dibawah ini sesuai dengan penilaian anda, dimana : 1 = Sangat Tidak Setuju $($ STS $) 3=$ Netral $(N)$ 5 = Sangat Setuju (SS) $2=$ Tidak Setuju (TS) 4 = Setuju (S)

\begin{tabular}{|c|l|c|c|c|c|c|}
\hline No & \multicolumn{1}{|c|}{ Pernyataan } & STS & TS & N & S & SS \\
\hline 1. & $\begin{array}{l}\text { Jika anda memperoleh kesempatan untuk } \\
\text { mendapatkan pekerjaan yang lebih baik di KAP } \\
\text { lain, anda akan menyetujuinya. }\end{array}$ & & & & & \\
\hline 2. & $\begin{array}{l}\text { Anda akan meninggalkan KAP tempat anda bekerja } \\
2 \text { tahun lagi. }\end{array}$ & & & & & \\
\hline 3. & $\begin{array}{l}\text { Anda akan meninggalkan KAP tempat anda bekerja } \\
5 \text { tahun lagi. }\end{array}$ & & & & & \\
\hline 4. & $\begin{array}{l}\text { Anda akan tetap berada pada KAP tempat anda } \\
\text { bekerja sampai masa pensiun. }\end{array}$ & & & & \\
\hline
\end{tabular}

\section{$\underline{\text { Pengalaman Auditor }}$}

Petunjuk : Berilah tanda $(\sqrt{ })$ pada pertanyaan dibawah ini sesuai dengan penilaian anda, dimana : $1=$ Sangat Tidak Setuju $($ STS $) 3=\operatorname{Netral}(\mathbf{N})$ 5 = Sangat Setuju (SS) $2=$ Tidak Setuju (TS) $\quad 4=$ Setuju $($ S)

\begin{tabular}{|c|l|c|c|c|c|c|}
\hline No & \multicolumn{1}{|c|}{ Pernyataan } & STS & TS & N & S & SS \\
\hline 1. & $\begin{array}{l}\text { Dengan melakukan perpindahan KAP memperkaya } \\
\text { pengalaman saya sebagai auditor. }\end{array}$ & & & & & \\
\hline 2. & $\begin{array}{l}\text { Kemampuan auditor dalam melakukan pengauditan } \\
\text { dapat tercermin dari banyaknya pengalaman yang } \\
\text { dimiliki. }\end{array}$ & & & & & \\
\hline 3. & $\begin{array}{l}\text { Menurut saya, pengalaman yang banyak } \\
\text { memudahkan auditor menemukan salah saji dan } \\
\text { mengembangkan temuan auditnya. }\end{array}$ & & & & & \\
\hline 4. & $\begin{array}{l}\text { Menurut saya, pengalaman tidak membantu saya } \\
\text { bernegosiasi dengan klien dengan baik. }\end{array}$ & & & & \\
\hline 5. & $\begin{array}{l}\text { Pengalaman tidak berpengaruh terhadap ketepatan } \\
\text { waktu dalam penyelesaian audit. }\end{array}$ & & & & \\
\hline
\end{tabular}




\section{$\underline{\text { Penghentian Prematur atas Prosedur Audit }}$}

Petunjuk : Berilah tanda $(\sqrt{ })$ pada pertanyaan dibawah ini sesuai dengan penilaian anda, dimana :

1 = Tidak Pernah $($ TP) 3 = Kadang-kadang $(K K)$ 5 = Selalu (S)

$\mathbf{2}=\mathbf{J a r a n g}(\mathbf{J})$

$4=$ Sering $(S R)$

\begin{tabular}{|c|c|c|c|c|c|c|}
\hline No & Pertanyaan & $\mathbf{T P}$ & $\mathbf{J}$ & KK & SR & $\mathbf{S}$ \\
\hline 1. & $\begin{array}{l}\text { Seberapa sering dalam merencanakan audit, anda } \\
\text { tidak emmerlukan pemahaman bisnis klien? }\end{array}$ & & & & & \\
\hline 2. & $\begin{array}{l}\text { Seberapa sering anda tidak menggunakan } \\
\text { pertimbangan Sistem Pengendalian Intern dalam } \\
\text { audit laporan keuangan? }\end{array}$ & & & & & \\
\hline 3. & $\begin{array}{l}\text { Seberapa sering anda tidak menggunakan informasi } \\
\text { asersi dalam merumuskan tujuan audit dan } \\
\text { merancang pengujian substantif? }\end{array}$ & & & & & \\
\hline 4. & $\begin{array}{l}\text { Seberapa sering anda tidak menggunakan fungsi } \\
\text { auditor internal dalam audit? }\end{array}$ & & & & & \\
\hline 5. & $\begin{array}{l}\text { Seberapa sering anda tidak melakukan prosedur } \\
\text { analitis dalam perencanaan dan review audit? }\end{array}$ & & & & & \\
\hline 6. & $\begin{array}{l}\text { Seberapa sering anda tidak melakukan konfirmasi } \\
\text { dengan pihak ketiga dalam audit laporan keuangan? }\end{array}$ & & & & & \\
\hline 7. & $\begin{array}{l}\text { Seberapa sering anda tidak menggunakan } \\
\text { representasi manajemen dalam audit laporan } \\
\text { keuangan? }\end{array}$ & & & & & \\
\hline 8. & $\begin{array}{l}\text { Seberapa sering anda tidak melakukan uji kepatuhan } \\
\text { terhadap pengendalian atas transaksi dalam aplikasi } \\
\text { sistem komputer on-line? }\end{array}$ & & & & & \\
\hline 9. & $\begin{array}{l}\text { Seberapa sering anda tidak mengurangi jumlah } \\
\text { sampel yang direncanakan dalam audit laporan } \\
\text { keuangan? }\end{array}$ & & & & & \\
\hline 10. & $\begin{array}{l}\text { Seberapa sering anda tidak melakukan perhitungan } \\
\text { fisik terhadap kas atau persediaan? }\end{array}$ & & & & & \\
\hline
\end{tabular}

